\title{
Professional misconduct and the anaesthetist
}

Not submitted in time for publication. 
G. Johnson MD

\section{L'anesthésiste et l'inconduite professionnelle}

Non encore reçu au moment de la publication. 